УДК 376.147.33:044.942

Коляда Михайло Георгійович

доктор педагогічних наук, доцент, завідувач кафедри інженерної та комп’ютаційної педагогіки

Інститут післядипломної освіти інженерно-педагогічних працівників Університету менеджменту освіти НАПН України, м. Донецьк, Україна

kolyada_mihail@mail.ru

\title{
ВИКОРИСТАННЯ ЗАКОНУ БРЕДФОРДА ДЛЯ ВИЗНАЧЕННЯ КІЛЬКОСТІ ЗАСВОСНИХ НА ЗАНЯТТІ НАВЧАЛЬНИХ ПОНЯТЬ
}

\begin{abstract}
Анотація. У статті розглядається один з імовірнісних законів розподілу як універсальний засіб пізнання і перетворення педагогічної дійсності. Показано, що модель, яка заснована на переробці одержуваної на занятті інформації утворює інформаційне відображення головних педагогічних чинників, принципів, закономірностей i законів. Метою статті $є$ показ використання закону Бредфорда для визначення кількості навчальних понять, засвоєних на занятті за критерієм їх цінності. Виявлено, що цей закон дає можливість не тільки науково виокремити зони значущості навчальних понять, що вивчаються на занятті, але й обгрунтовано обчислити їх взаємозалежний кількісний склад.
\end{abstract}

Ключові слова: засвоювання матеріалу; навчальне поняття; зони значущості навчальних понять; закон Бредфорда.

\section{1. ВСТУП}

Актуальність теми дослідження. Соціально-педагогічна значущість досліджуваної проблеми визначається розв'язанням складної дидактичної проблеми - визначення кількості засвоєних на занятті навчальних понять. Актуальність проблеми використання ефективних шляхів засвоєння навчального матеріалу на занятті приводить до необхідності пошуку адекватних проблемі способів розв'язання різних за напрямом педагогічних завдань, зокрема розрахунку оптимальної кількості базових i периферійних (обслуговуючих) навчальних понять. Використання освітніх ресурсів навчального процесу здійснюється із застосуванням відповідних закономірностей і законів, які дають підстави для оптимального розподілу сил викладача і тих, кого навчають, заздалегідь націлюють суб' єкти навчальної діяльності на можливі труднощі, дають підстави раціонально використовувати час, відведений на засвоєння матеріалу, що вивчається на занятті.

Історія та постановка проблеми у загальному вигляді. Довгий час аналіз законів, за якими будується складне активне відображення дійсності тим, кого навчають, його активна увага, довільне запам'ятовування, формування абстрактних понять, аналіз складних форм активної діяльності і процесу логічної побудови міркувань, тобто активної психічної діяльності, - усе це залишалося за межами уваги провідних науковців.

Уперше ці питання були розглянуті видатними психологами минулого сторіччя Л. С. Виготським і О. М. Леонтьєвим, які по-новому розкрили діяльнісні можливості людини і визначили інноваційний погляд на форми свідомих процесів особистості в навчальній діяльності [7; 9]. У п'ятдесяті роки XX століття нова в той час наука кібернетика ввела як основне поняття дефініцію «саморегулювання», i зробила центральним предметом свого дослідження структуру саморегулюючих систем. У цей же час, у математиці такі ж ідеї проявилися у вигляді виникнення і розвитку теорії інформації і теорії випадкових процесів.

Істотні відкриття були зроблені й у фізіології. Центральне для цієї науки поняття «рефлекторної дуги» було замінено поняттям «рефлекторного кільця», а ідея рефлексу 
збагатилася і доповнилася новими поглядами: П. К. Анохіним була висунута ідея функціональних систем. Також було зроблено вирішальний крок у розвитку фізіології рефлексів: М. О. Бернштейном було розроблено так звану «фізіологію активності», що впритул підійшла до наукового аналізу фізіологічних механізмів найбільш складних і активних форм людської діяльності.

Наприкінці 60-х років минулого століття американські психологи П. Ліндсей i Д. Норман опублікували свою базову роботу «Переробка інформації у людини» [8], якою поклали початок науковому підходу у дослідженні ефективного засвоєння навчального матеріалу на занятті.

Перелічена база досягнень споріднених наук підштовхнула й педагогівдослідників до аналізу процесів переробки навчальної інформації у тих, кого навчають. Так, український дослідник I. П. Підласий обгрунтував діагностику й експертизу педагогічних проектів, у рамках якої було досконало розроблено діагностику навченості тих, кого навчають [13; 14], науковці Т. М. Канівець і Л. І. Лутченко заклали основи педагогічного оцінювання [5; 10]. Але ж їх центральною ідеєю була спроба підійти до переробки одержуваної на занятті інформації як до складної активної діяльності, побудованої за ймовірнісними законами. Педагоги почали досліджувати питання розуміння навчального тексту i його складності. Спробували дослідити показники труднощів навчального матеріалу, а саме: інформативність, абстрактність навчальних понять і складність їх структури [12]. Навіть розробили рекомендації 3 підвищення зрозумілості навчального матеріалу, але проблемі співвіднесення навчальних понять за рівнями їх значущості, співвідношенню базових, обслуговуючих i другорядних навчальних понять не достатньо приділялося уваги у працях науковців. Тому нами було обрано тему статті, пов'язану з використанням закону, що би дав змогу не тільки обчислити кількісний склад базових навчальних понять, які повинні засвоюватися тими, кого навчають, але й показати зв'язок цих понять із другорядними $\mathrm{i}$, так званими, обслуговуючими поняттями. Метою статті $є$ показ використання закону Бредфорда для визначення кількості навчальних понять для їх засвоєння на занятті за критерієм їх значущості.

\section{2. РЕЗУЛЬТАТИ ДОСЛІДЖЕННЯ}

\section{1. Сутність закону Ципфа}

У процесах погодженості елементів навчальної діяльності найчастіше використовують класичні закони (наприклад, закон нормального розподілу) і методи (наприклад, метод транспортної задачі, метод кутового перетворення та інші), але іноді для процесів кількісного визначення навчальних об'єктів використовують й ненормальні (тобто не Гаусові) закони розподілу. До них можна віднести так званий закон Ципфа.

Наприкінці 40-x років минулого сторіччя професор-лінгвіст і філолог Гарвардського університету Джордж Кінгслі Ципф (George Kingsley Zipf, 19021950 рр.), зібравши величезний статистичний матеріал, спробував показати, що розподіл слів природної мови підкоряється одному простому закону, який можна сформулювати так. Якщо до якого-небудь досить великого тексту скласти список усіх слів, щзо зустрічалися в ньому, потім розташувати иі слова в порядку убування їх частотності в цььому тексті і пронумерувати в порядку від 1 (порядковий номер найбільш частотного слова) до $r$, то для будь-якого слова добуток його порядкового номера (рангу) у такому списку і його частотності в тексті буде величиною постійною, щз має приблизно однакове значення для будь-якого слова з иъого списку. Аналітично закон Ципфа може бути виражений у такий спосіб: 


$$
f r=c,
$$

де $f$ - частотність слова в тексті; $r$ - ранг (порядковий номер) слова в списку; с емпірична постійна величина.

Отримана залежність графічно виражається гіперболою. Пізніше Б. Мандельброт запропонував його теоретичне обгрунтування. Він розмірковував, що можна порівнювати письмову мову з кодуванням, причому всі знаки повинні мати визначену «вартість». Виходячи 3 вимог мінімальної вартості повідомлень, Б. Мандельброт математичним шляхом дійшов до аналогічного закону Ципфа у вигляді подібної залежності [16, с. 47]:

$$
f r^{\gamma}=\text { const, }
$$

де $\gamma$ - величина (близька до одиниці), яка може змінюватися залежно від властивостей тексту.

\section{2. Визначення кількості засвосних на занятті навчальних понять на засадах закону Бредфорда}

Навчальні поняття як ментальні конструкти є найважливішими компонентами безупинної зміни і розширення пізнавальної структури індивідуума, що розвивається. Під терміном «навчальне поняття» розуміють базову, фундаментальну значеннєву одиницю навчального матеріалу, що виступає не тільки у вигляді ментальних конструктів, тобто таких, які обумовлені напрямом думок людей цієї предметної галузі разом із їх духовними установками, але й у вигляді значення слів, символів (формул) та інших об'єктів, що використовуються у середовищі думок, суджень, поглядів і позицій фахівців.

Більшість педагогів-дослідників замість терміна «навчальне поняття» використовують інше формалізоване, тотожне йому словосполучення: показник інформаційно-значеннєвих елементів тексту (в іншій редакції: інформаційно-змістових елементів тексту - IЗЕТ). Вони визначаються у формі суджень як завершені за змістом найпростіші предметні структури, під час членування яких втрачається їхній зміст (сенс). IЗET — це не поняття (у широкому сенсі слова) і не речення, це прості судження, з яких складаються поняття. В одному реченні може міститися кілька IЗET [14, с. 437]. Виходячи з того, що і навчальні поняття, i IЗЕT практично тотожно відбивають те ж саме структурне утворення, ми для зручності розгляду будемо використовувати дефініцію I3ET.

Як приклад конкретного використання показника інформаційно-значеннєвих елементів тексту, можна навести одержану емпіричним шляхом у 1989 році В. П. Беспальком формулу підрахунку дидактичного обсягу засвоєння навчального матеріалу з урахуванням мети навчання [3, с. 86]:

$$
Q=(N \Delta \beta H \gamma) /\left(1-K_{\tau}\right) \text {, }
$$

де $N$ - кількість IЗЕТ, $\Delta \beta$ - середній приріст якості засвоєння за рівнем засвоєння і ступенем абстракції матеріалу, $H$ - середній обсяг формальної інформації в одному IЗЕT (у бітах, одне слово несе інформацію в 12-14 біт), $\gamma$ - ступінь усвідомленості матеріалу $(\gamma=1,2,3$, де число показує рівень аргументації вибору орієнтувальної основи дії: 1 - у межах однієї задачі, 2 - в межах однієї або кількох близьких дисциплін, 3 - у межах широких міжпредметних зв'язків багатьох дисциплін), $K_{\tau}-$ коефіцієнт засвоєння матеріалу: $K_{\tau}=\tau_{y u} / \tau_{\phi a x}$, де $\tau_{\text {уч }}$ - середній час виконання тестової проби учня (студента), $\tau_{\text {фax }}$ - середній час виконання тестової проби кваліфікованим фахівцем.

3 погляду проблеми з'ясування закономірностей щодо погодженості педагогічних 
об'єктів було встановлено той факт, що деякі величини всередині якої-небудь галузі знань можуть розподілятися відповідно до закону Ципфа. Частковим його випадком $\epsilon$ закон, який було сформульовано англійським хіміком і бібліографом С. Бредфордом. Він безпосередньо пов' язаний не з розподілом слів у тексті, а з розподілом документів усередині якої-небудь тематичної галузі.

3 погляду дидактики, у змісті будь-якого навчального матеріалу прийнято виділяти дві частини [11]. До першої частини відноситься інформація, що безпосередньо складає зміст предмету, предметні знання, чи ЗМІСТ-1. Друга частина - ЗМІСТ-2 - це інформація, що обслуговує ЗМІСТ-1 (наприклад, знання з інших курсів, викладення, тлумачення, пояснення). Це так звані фонові знання, інформація про застосування і використання ЗМІСТУ-1 в інших дисциплінах, у житті і т. ін.

Інженерія знань у текстових джерелах знань (у тому числі й у підручниках, лекційному матеріалі і т. п.) виділяє первинний матеріал спостережень, систему наукових понять, суб'єктивні погляди автора і результат його особистого досвіду, а також деякі «загальні місця», або «воду». Відповідно до цього можна говорити про наявність у навчальному матеріалі заняття поряд зі 3МІСТОМ-1 і 3МІСТОМ-2 також ЗМІСТУ-3, що відповідає, в основному, знанням типу «вода», назвемо цю інформацію периферійною. Наша практика складання семантичних предметних моделей показує, що ЗМІСТ-3 іноді, особливо в підручниках для загальноосвітніх курсів, може досягати надзвичайно великих обсягів.

За своєю суттю, саме 3МІСТ-1 (назвемо цю інформацію - ключовою, базовою) i складає семантичну модель предметної галузі, яку ми назвемо «Зоною значущьсті-1», відповідно ЗМІСТ-2 і ЗМІСТ-3 назвемо «Зоною-2» і «Зоною-3». Однак ці знання, наприклад, у підручнику не виділені спеціально, вони розподілені по всьому підручнику, переплітаються з іншими знаннями, вони не формалізовані.

Нашим завданням є визначення кількості нових базових (ключових) IЗET, що повинні бути засвоєні учнями (студентами) відносно їх загальної кількості на одному занятті, включаючи вже засвоєні. Використаємо для цього закономірність С. Бредфорда.

Сутність іiі стосовно нашої задачі $€$ в тому, що якщо всі IЗET розташувати за убуванням кількості їх значимості, то кількість IЗЕТ в отриманому списку можна розбити на три зазначені вище зони так, щоб кількість базових IЗET у кожній із цих зон була однаковою (механізм визначення рейтингу значущості I3ET можна знайти у роботах $[1 ; 15])$. При цьому до першої зони, так звану зону ядра, входять тільки базові (ключові) IЗET, які є основою розгляду заданої теми дисципліни (курсу). Кількість цих головних IЗET у зоні ядра невелика. Другу зону утворює та ж кількість базових IЗET, разом із частково обслуговуючими IЗET заданої предметної сфери, причому їхня загальна кількість істотно зростає порівняно з кількістю першої зони. До них відносять і кількість IЗET, які є єднальними з IЗET базового ядра; це можуть бути вже вивчені інформаційно-значеннєві одиниці, без яких IЗЕT базового ядра засвоїти дуже складно, а часом й неможливо. Третя зона - найбільша за кількістю різнопланових I3ET; вона поєднує більшість інформаційно-значеннєвих одиниць тексту, зміст яких дуже далекий від розглянутої теми заняття. Крім тієї ж кількості базових IЗЕT сумісних з єднальними IЗET другої зони, сюди входять ще й I3ET другорядного плану, які не мають прямого відношення до IЗET базового ядра - це поняття загального характеру, комунікаційні елементи, загальнообслуговуючі та ін. (так звані IЗЕT типу «вода»).

Отже, за однакової кількості базових IЗET за визначеною темою заняття у кожній зоні загальна кількість IЗЕT різної категорії різко зростає при переході від однієї зони до іншої. Використовуючи ідеї С. Бредфорда, було встановлено, що кількість IЗЕТ у третій зоні буде приблизно в стільки разів більшою порівняно з другою зоною, у 
скільки разів кількість ІЗЕТ другої зони більше відносно кількості IЗЕТ першої зони.

Позначимо $P_{1}$ як загальну кількість IЗET у 1 -й зоні, $P_{2}-$ у 2 -й, $P_{3}-$ загальну кількість IЗЕТ у 3-й зоні. Якщо прийняти параметр $a$ як відношення загальної кількості IЗET 2-ї зони щодо кількості загальних IЗЕT 1-ї зони, то закономірність, що була підмічена С. Бредфордом, може бути записана так:

$$
P_{1}: P_{2}: P_{3}=1: a: a^{2}
$$

або

$$
P_{3}: P_{2}=P_{2}: P_{1}=a \text {. }
$$

Цю залежність й називають законом Бредфорда. Так, якщо розташувати базові IЗЕT за убуванням кількості їхньої значимості, то, згідно із законом Бредфорда, їх можна розбити на три групи, що містять їх рівну чисельність. 3 теорії ми знаємо, що на одному занятті якісно можна засвоїти близько 7 базових IЗET, що займають перші 7 місць в отриманому списку (див. [6, с. 223]). Тоді для того, щоб подвоїти кількість засвоєних базових IЗЕТ на одному занятті, нам доведеться додати до наявних 7 ще $7 * a$ загальних I3ET. Якщо прийняти $a=5$ (це значення знайдено експериментальним шляхом для деяких тематичних галузей), то кількість цих найменувань стане дорівнювати 35. Тоді загальна кількість усіх ІЗЕТ складатиме $7+35=42$, що, звичайно, значно більше, ніж 7 початкових. При спробі ж засвоїти втроє більшу кількість базових IЗЕT, нам доведеться охопити вже $7+5 * 7+25 * 7=217$ загальних IЗЕТ! Це свідчить про те, що при збільшенні інтенсивності вивчення нового матеріалу вдвічі, «шумовий фон», тобто труднощі цієї процедури, зростає у 6 разів, а при збільшенні інтенсивності в три рази - труднощі зростають у 31 раз!

Тому інтенсифікація навчального процесу стосовно базових знань (у вигляді навчальних понять) завжди супроводжується великими труднощами і перешкодами зі сторони другорядного («шумового») матеріалу.

\section{3. ВИСНОВКИ}

Отже, моделювання, що засноване на переробці одержуваної на занятті інформації як складної активної діяльності тих, кого навчають, побудованої за ймовірнісними законами, має тільки перші кроки свого становлення. Ще не обгрунтовано критерії оптимальної складності засвоєння навчальних понять, не визначено методи вимірювання труднощів їх засвоювання. Але ж застосування деяких специфічних методик i законів розподілу дає підстави для ефективного їх використання. Серед них достойне місце займає закон С. Бредфорда, який дає можливість не тільки науково виокремити зони значущості навчальних понять, що вивчаються на занятті, але й обгрунтовано обчислити їх взаємозалежний кількісний склад. Це дає могутній інструмент педагогу-досліднику для розрахунку напруженості праці того, кого навчають, під час засвоювання ним нових інформаційно-значеннєвих елементів тексту на занятті.

\section{СПИСОК ВИКОРИСТАНИХ ДЖЕРЕЛ}

1. Атанов Г. А. Моделирование учебной предметной области, или предметная модель обучаемого / Геннадий Алексеевич Атанов // Educational Technology \& Society. - 2000. — № 3 (3). - C. 111124.

2. Бабанский Ю. К. Оптимизация педагогического процесса (в вопросах и ответах) / Ю. К. Бабанский, М. М. Поташник. - К. : Рад. школа, 1984. - 188 с.

3. Беспалько В. П. Слагаемые педагогической технологии / В. П. Беспалько. - М. : Педагогика, 1989. - $192 \mathrm{c}$. 
4. Гальперин П. Я. Основные результаты исследований по проблеме «Формирование умственных действий «понятий». Доклад, представленный на соискание докт. степени (по психологии). - М., 1965. - $74 \mathrm{c}$.

5. Канівець Т. М. Основи педагогічного оцінювання : навч.-метод. посіб. / Т. М. Канівець. - Ніжин : Видавець ПП Лисенко М. М., 2012. - 102 с.

6. Коляда М. Г. Комп'ютаційна педагогіка : навчальний посібник / Михайло Георгійович Коляда. К : УМО НАПН України, 2013. - 321 с.

7. Леонтьев А. Н. Деятельность. Сознание. Личность / А. Н. Леонтьев. - М. : Academia, 2005. - 352 c.

8. Линдсей П. Переработка информации у человека / П. Линдсей, Д. Норман. - М. : Мир, 1974. — $538 \mathrm{c.}$

9. Выготский Л. С. Педагогическая психология / Л. С. Выготский; под ред. В. В. Давыдова. - М. : Педагогика-Пресс, 1996. - 536 с.

10. Лутченко Л. І. Основи педагогічного оцінювання : навч.-метод. посіб. / Л. І. Лутченко, Н. О. Пасічник. - Кіровоград : Лисенко В. Ф, 2012. - 72 с.

11. Машбиц Е. И. Психологические основы управления учебной деятельностью / Е. И. Машбиц. К. : Вища школа, 1987. - 224 с.

12. Микк Я. А. Оптимизация сложности учебного текста: В помощь авторам и редакторам / Яан Арнольдович Микк. - М. : Просвещение, 1981. - 119 с.

13. Підласий І. П. Діагностика та експертиза педагогічних проектів. - К. : Україна, 1998. — 343 с.

14. Подласый И. П. Продуктивная педагогика : книга для учителя / И. П. Подласый. - М. : Народное образование, 2003. - 496 с.

15. Програмований опорний конспект із фізики : навч. посібник / [уклад. Г. О. Атанов, Т. Д. Біла, Б. І. Бешевлі та ін.]. — К. : НМК ВО, 1993. — 108 с.

16. Чурсин Н. Популярная информатика / Николай Чурсин. - К. : Техника, 1982. — 86 с.

Матеріал надійшов до редакиії 24.01.2014 p.

\title{
ИСПОЛЬЗОВАНИЕ ЗАКОНА БРЕДФОРДА ДЛЯ ОПРЕДЕЛЕНИЯ КОЛИЧЕСТВА УСВОЕННЫХ НА ЗАНЯТИИ УЧЕБНЫХ ПОНЯТИЙ
}

\section{Коляда Михаил Георгиевич}

доктор педагогических наук, доцент, заведующий кафедрой инженерной и компьютационной педагогики Институт последипломного образования инженерно-педагогических работников Университета менеджмента образования НАПН Украины, г. Донецк, Украина kolyada_mihail@mail.ru

\begin{abstract}
Аннотация. В статье рассматривается один из вероятностных законов распределения как универсальное средство познания и преобразования педагогической действительности. Показано, что модель основанная на переработке получаемой на занятии информации, образовывает информационное отображение главных педагогических факторов, принципов, закономерностей и законов. Целью статьи является показ использования закона Бредфорда для определения на занятии количества учебных понятий для усвоения, с учетом критерия их ценности. Выявлено, что этот закон дает возможность не только научно выделять зоны значимости учебных понятий, которые изучаются на занятии, но и обоснованно вычислять их взаимозависимый количественный состав.
\end{abstract}

Ключевые слова: усваивание материала; учебное понятие; зоны значимости учебных понятий; закон Бредфорда.

\section{USE OF LAW BREDFORD FOR DETERMINATION OF QUANTITY OF ACQUIRED EDUCATIONAL CONCEPTS AT THE LESSONS}

\section{Mykhailo H. Koliada}

Doctor in Pedagogical sciences, professor, Head of the Department of engineering and computational pedagogics Institute of Post-graduate Education of Engineering-pedagogical Workers of University of Management in Education of NAPS of Ukraine, Donetsk, Ukraine

kolyada_mihail@mail.ru 


\begin{abstract}
In the article one of likelihood laws of distribution as a universal remedy of knowledge and transformation of the pedagogical validity is considered. It is shown that model which is based on processing of the information received at the lesson, creates information display of the main pedagogical factors, principles and laws. The article aims to display the use of the Law Bredford for determination of quantity of acquired educational concepts at the lessons taking into account criterion of their value. It is revealed that this law gives the chance not only to allocate scientifically zones of the importance of educational concepts which are studied at the lessons, but also to calculate their interdependent quantitative structure.
\end{abstract}

Keywords: material assimilation; educational concept; zones of the importance of educational concepts; the law of Bredford.

\title{
REFERENCES (TRANSLATED AND TRANSLITERATED)
}

1. Atanov G. A. Modeling of educational subject domain, or subject model of the trainee / Gennady Alekseevich Atanov // Educational Technology \& Society. — 2000. — № 3 (3) - P. 111-124.

1. (in Russian)

2. Babansky Ju. K. Optimization of pedagogical process (in questions and answers) / Ju. K. Babansky, M. M. Potashnik. — K. : The Soviet School, 1984. — 188 p.(in Russian)

3. Bespalko V. P. Century of the Item Composed pedagogical technology / V .P. Bespalko. - M. : pedagogics, 1989. - 192 p.(in Russian)

4. Galperin P. Ja. The basic results of researches on a problem «Formation of intellectual actions of «concepts». The report presented on competition of doctor's degree (on psychology). — M., 1965. — 74 p.(in Russian)

5. Kanivets T. M. Of the Basis of pedagogical estimation : the Uchebno-methodical grant / T. M. Kanivets. — Nizhyn : the publisher of software Lysenko V. F, 2012. — 102 p. (in Ukrainian)

6. Koliada M. G. Computational pedagogic : the manual / Mihajlo Georgijovich Koliada. — K. : UMO NAPN Ukraine, 2013. - 321 p.(in Ukrainian)

7. Leontev A. N. Activity. Consciousness. The person / A. N. Leontev. - M. : Academia, 2005. 352 p.(in Russian)

8. Lindsej P. Processing of the information at the person / P. Lindsej, D. Norman. — M. : «World», 1974. - 538 p.(in Russian)

9. Vygotsky L. S. Pedagogical psychology / L. S. Vygotsky; under V. V. Davidov's edition. - M. : Pedagogics-press, 1996. - 536 p.(in Russian)

10. Lutchenko L. I. Of the Basis of pedagogical estimation : the Uchebno-methodical grant / L. I. Lutchenko, N. A. Pasichnik. - Kirovograd : Lysenko V. F, 2012. - 72 p.(in Ukrainian)

11. Mashbits E. I. Psychological bases of management of educational activity / E. I. Mashbits. - K. : the Higher school, 1987. - 224 p.(in Russian)

12. Mikk Ja. A. Optimization of complexity of the educational text : For the aid to authors and editors / Jaan Arnoldovich Mikk. — M. : Education, 1081. — 119 p.(in Russian)

13. Pidlasyj I. P. Diagnostics and examination of pedagogical projects. — K. : «Ukraine», 1998. — 343 p.(in Ukrainian)

14. Podlasyj I. P. Productive pedagogics: the Book for the teacher / I. P. Podlasyj. - M. : National education, 2003. - 496 p.(in Russian)

15. The programmed basic abstract on the physicist: the Manual / Composer G. O. Atanov, T. D. Belaja, B. I. Beshevli, etc. - K. : NMK VO, 1993. - 108 p.(in Ukrainian)

16. Chursin N. Popular computer science / Nikolay Chursin. - K. : Technics, 1982 — 86 p.(in Russian) 